\title{
PLANT REMAINS AND AMS: DATING CLIMATE CHANGE IN THE AEOLIAN ISLANDS (NORTHEASTERN SICILY) DURING THE 2ND MILLENNIUM BC
}

\begin{abstract}
V Caracuta $^{1} \cdot \mathrm{G}_{\text {Fiorentino }}{ }^{1,2} \cdot \mathrm{M} \mathrm{C} \mathrm{Martinelli}^{3}$
ABSTRACT. Archaeological plant remains, used to establish a reliable chronology by radiocarbon dating, are used here to investigate trends in past rainfall intensity. The stable carbon isotope ratio in botanic remains depends on environmental conditions during the plant's life. By comparing the $\delta^{13} \mathrm{C}$ and ${ }^{14} \mathrm{C}$ of selected plant specimens from 3 protohistoric sites in the Aeolian Archipelago, it is possible to identify short-term changes in the rainfall intensity during the $2 \mathrm{nd} \mathrm{millennium} \mathrm{BC}$. The climate signals inferred from carbon isotope analyses are compared to pollen data for the region and are found to be consistent with changes in vegetal cover. Finally, the climate signals are integrated with the history of the Aeolian communities and the resilience of settlers is evaluated.
\end{abstract}

\section{INTRODUCTION}

Charred plant remains collected in archaeological sites are commonly used to infer information on natural vegetal cover, food production, trade exchange, and agricultural practices (Zohary and Hopf 2000; Théry-Parisot et al. 2010). Recently, the traditional archaeobotanical approach has been further developed and vegetal macroremains have been used to identify short-term climate changes (Roberts et al. 2011; Fiorentino et al. 2012a).

Studies indicate that plant remains, which record chemical-physical environmental characteristics by their stable isotope ratios, are suitable for this type of research. In particular, plant water input (O'Leary 1995) has been found to be related to the stable carbon isotope ratio, and the plant's $\delta^{13} \mathrm{C}$ value can thus be used to identify variation in the rainfall regime.

Modern accelerator mass spectrometry (AMS) instruments measure ${ }^{14} \mathrm{C} /{ }^{12} \mathrm{C}$ and ${ }^{13} \mathrm{C} /{ }^{12} \mathrm{C}$ isotope ratios simultaneously, which can be interpreted to correlate past precipitation changes to an absolute timescale (Fiorentino et al. 2008, 2009). Assuming that short-term climate fluctuations affect settlement and subsistence patterns, especially in regions that are environmentally marginal, we applied carbon isotope analysis to plant remains from 3 protohistoric sites in the Aeolian Archipelago.

In total, 33 plant samples collected from the protohistoric villages of Filo Braccio, Portella, and Punta Milazzese were analyzed by AMS. The paleoclimate trend inferred from the carbon isotope analysis was compared to the regional pollen diagram of Gorgo Basso (SW Sicily) to verify whether changes in vegetal cover recorded in pollen sequences were consistent with climate signals. This record was preferred to other regional sequences (e.g. Pergusa Lake, Sadori et al. 2008) because, despite its distance from the Aeolian Archipelago, it has similar Mediterranean environmental characteristics.

Gorgo Basso is a coastal lake $(6 \mathrm{~m}$ asl) situated in a belt of thermo-Mediterranean oaks (Quercus ilex) and evergreen shrubs (Pistacia lentiscus), where local vegetation is very sensitive to changes in availability of water (Tinner et al. 2009). Our isotope data are compared with archaeological records in order to investigate the resilience of the island's communities. The results indicate correlations between starvation caused by water shortage, plant coverage, and human dynamics.

\footnotetext{
${ }^{1}$ Laboratory of Archaeobotany and Palaeoecology, University of Salento, Lecce, Italy.

2Corresponding author. Email: girolamo.fiorentino@unisalento.it.

${ }^{3}$ Regional Board of the Archaeological Park of Aeolian Islands, Archaeological Museum L. Bernabò Brea, Lipari, Messina, Italy.
}

(C) 2012 by the Arizona Board of Regents on behalf of the University of Arizona Proceedings of the 6th International Radiocarbon and Archaeology Symposium, edited by E Boaretto and N R Rebollo Franco RADIOCARBON, Vol 54, Nr 3-4, 2012, p 689-700 


\section{CONTEXT OF THE STUDY}

\section{Geographical Setting}

The Aeolian Archipelago, located in the southern Tyrrhenian Sea west of Calabria and north of Sicily, consists of 10 islands and islets, of which only 7 are populated. The largest island is Lipari, with a surface area of $37.3 \mathrm{~km}^{2}$, while the other islands are Vulcano, Salina, Stromboli, Filicudi, Alicudi, and Panarea (Figure 1). The archipelago is of volcanic origin and all the islands were submarine volcanoes that emerged about $700 \mathrm{kyr}$ ago (Maramai et al. 2005).

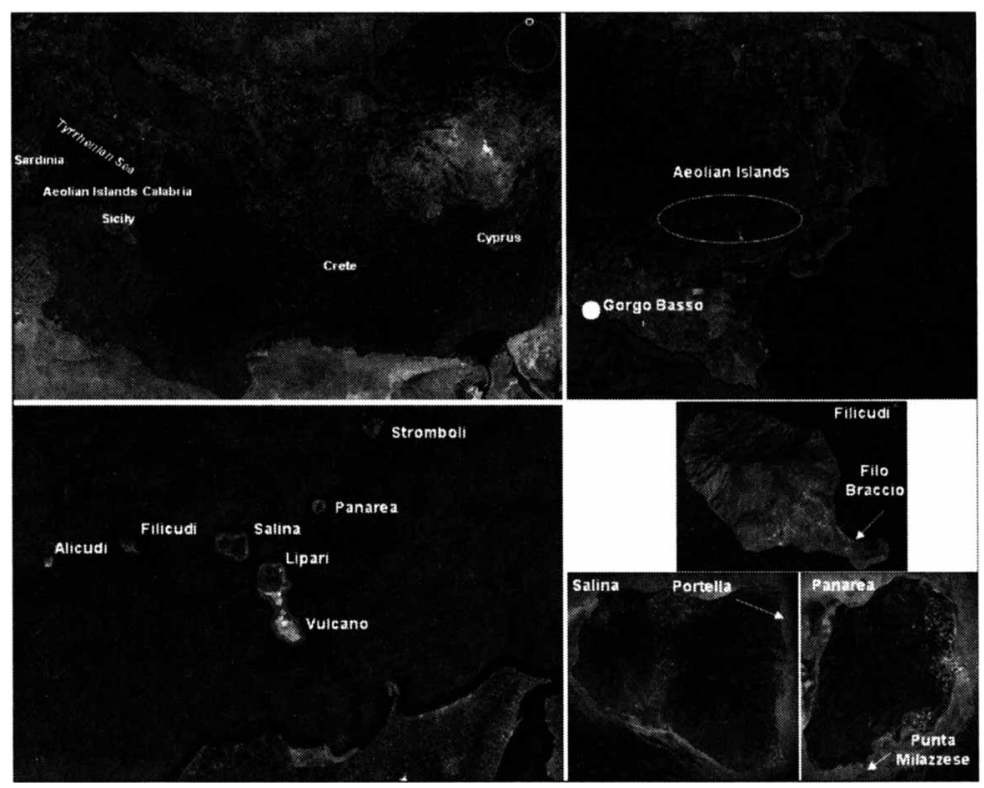

Figure 1 The Aeolian Islands and Gorgo Basso within the Mediterranean Basin

Geological traits influence the landscape morphology, soil, and range of natural resources. All the islands have sharp profiles and arable plains are limited to Lipari (Diana) and Filicudi (Filo Braccio) (Morelli et al. 1975). The maximum elevation ranges from $420 \mathrm{~m}$ asl on Panarea to $961 \mathrm{~m}$ asl on Salina, causing variation in rainfall. The average annual precipitation in Salina is $\sim 650 \mathrm{~mm}$ per year, but only $400 \mathrm{~mm}$ in Panarea, resulting in differences in biodiversity and water availability. As a whole, the archipelago belongs to the subarid Mediterranean climatic zone (Troia 1998).

Lack of perennial water resources and a dearth of arable land limit the possibility of extensive agriculture, exposing human communities to the risk of famine and starvation. The carrying capacity of the island system, defined as the potential to sustain a certain human population in equilibrium (Williamson and Sabath 1984), is not only determined by environmental parameters (biodiversity, resources fluctuation, rainfall, land area), since cultural variables (technology, cultural perception of resources, external relations) have always influenced human dynamics in the archipelago.

\section{Historical Framework}

The Aeolian Archipelago has a long history of human occupation, beginning in the 5 th millennium BC, during the Neolithic, when settlers first moved from Sicily towards Lipari in search of obsidian. During the Bronze Age, the Aeolians prospered thanks to maritime commerce. The transition from 
the Early Bronze Age to the Late Bronze Age (2100-900 BC) was characterized by at least 3 different cultural phases: Capo Graziano; Milazzese; and Ausonio (Bernabò Brea and Cavalier 1968).

During Capo Graziano phase 1, the settler economy seems to have been oriented towards farming, and villages flourished on the coastal plains of Filo Braccio (Filicudi) and Diana (Lipari). Evidence from cultural materials shows that during this phase, the Aeolian sites shared models in pottery manufacture and dwellings that were characteristic of contemporary southern Italian communities (Bernabò Brea and Cavalier 1991).

During Capo Graziano phase 2, changes occurred in the distribution of settlements: the lowlands were abandoned and villages were built in strategic positions on hilltops such as La Montagnola (Filicudi) and Acropolis (Lipari). Contacts with the Mycenaeans intensified, as indicated by significant quantities of imported Mycenaean pottery and the adoption of specific architecture, such as the tholos, typical of the Aegean tradition.

The role of the Aeolian Islands within the Mediterranean trading system was consolidated during the Middle Bronze Age, especially during the Milazzese phase, when the number of sites increased to 3 and inaccessible promontories were occupied in Portella (Salina), Punta Milazzese (Panarea), and Acropolis (Lipari) (Martinelli 2005). Bietti-Sestieri (2010) suggests that the Mycenaeans may have used the Aeolian Islands as offshore trading centers: neutral territories in which commercial transactions could take place, in much the same way as the Minoans used the islands of the western and eastern Aegean, establishing close alliances with small island groups as a means of gaining access to wider networks of contacts.

This system collapsed during the Late Bronze Age, when the Aeolian Islands were occupied by the Ausonians, a new group of intruders from the Italian Peninsula who destroyed all the settlements except the Acropolis of Lipari. Systematic reoccupation started in the 6th century BC when Greek exiles from Rhodes and Knidos landed at Lipari, starting a period of Greek domination, which was known for acts of piracy against Etruscan and Phoenician shipping.

\section{PALEOCLIMATE RESEARCH: THEORETICAL BACKGROUND}

\section{$\delta^{13} \mathrm{C}$ of Archaeological Plant Remains: Implications for Paleoclimate Studies}

Stable carbon isotope analysis of ancient plant remains has been widely used to identify ancient climate changes in northwest Europe, Syria, and south Italy (Vernet et al. 1996; Fiorentino et al. 2008, 2009; Riehl et al. 2008). All these paleoclimatic studies are based on the principle that during photosynthesis the carbon pathway is influenced mostly by environmental parameters (Ehleringer et al. 1993). The discrimination (isotope fractionation) of ${ }^{12} \mathrm{C}$ and ${ }^{13} \mathrm{C}$ occurs mainly, but not exclusively, during the passage of $\mathrm{CO}_{2}$ through the stomata in the leaf. In principle, under conditions of environmental stress the stomata close up and the amount of $\mathrm{CO}_{2}$ available for photosynthesis is reduced. In plants with a $\mathrm{C}_{3}$ photosynthetic pathway, the carboxylating enzyme ( $\left.\mathrm{RuBis} C \mathrm{C}\right)$ is then forced to fix a higher proportion of ${ }^{13} \mathrm{CO}_{2}$, and the ${ }^{13} \mathrm{C} /{ }^{12} \mathrm{C}$ isotope ratio increases (Ferrio et al. 2005). A simple model most widely used to describe isotopic fractionation in photosynthesis in leaves is that of Farquhar et al. (1989), who argued that variations in the leaf carbon isotope ratio ${ }^{4}\left(\delta^{13} \mathrm{C}_{\text {plant }}\right)$ of $\mathrm{C}_{3}$ plants depends on the intercellular $\mathrm{CO}_{2}$ concentration (ci) as follows:

\footnotetext{
${ }^{4}$ The stable carbon isotope composition of a given sample is expressed as the difference between the ${ }^{13} \mathrm{C} /{ }^{12} \mathrm{C}$ ratio measured for the sample $\left(\mathrm{R}_{\text {sample }}\right)$ and the PDB (Pee Dee belemnite) standard ratio in permil deviation: $\delta^{13} \mathrm{C}(\%)=\left(\mathrm{R}_{\text {sample }} / \mathrm{R}_{\text {standard }}-\right.$ 1) $\times 1000$.
} 


$$
\delta^{13} \mathrm{C}_{\text {plant }}=\delta^{13} \mathrm{C}_{\mathrm{air}}-a-(b-a) c_{i} / c_{a}
$$

where $\delta^{13} \mathrm{C}_{\text {air }}$ is the carbon isotope ratio of $\mathrm{CO}_{2}$ in the air, $a$ is the fractionation caused by the slower diffusion of ${ }^{13} \mathrm{CO}_{2}$ relative to ${ }^{12} \mathrm{CO}_{2}, b$ is the fractionation caused by discrimination of the enzyme RuBisCO against ${ }^{13} \mathrm{CO}_{2}$, and $c_{a}$ is the atmospheric $\mathrm{CO}_{2}$ concentration (Farquhar et al. 1982). The only parameter under the direct control of the plant is $c_{i}$, which depends on stomatal conductance and the carboxylation rate. Thus, if environmental factors cause the plant to increase its stomatal conductance and/or decrease its carboxylation rate, then the resulting increase in $c_{i}$ will produce a lower $\delta^{13} \mathrm{C}_{\text {plant }}$ (Heaton 1999).

This would imply that $\delta^{13} \mathrm{C}_{\text {plant }}$ may depend on either variations in atmospheric $\mathrm{CO}_{2}$ concentration and relative $\delta^{13} \mathrm{C}_{\text {air }}$ or changes in photosynthesis due to environmental factors. The $\delta^{13} \mathrm{C}$ of atmospheric $\mathrm{CO}_{2}$ is currently around $-8 \%$ (Ferrio et al. 2005), with latitudinal (Taylor and Orr 2000) and chronological variations in relation to complex carbon cycle mechanisms (Mayewski et al. 2004), deforestation, and the use of fossil fuels (McCarroll and Loader 2004).

The $\delta^{13} \mathrm{C}$ of $\mathrm{CO}_{2}$ during the 2 nd millennium has been found to be higher $(-6.36 \%$ ) than that of modern times (-8.05\%) (Ferrio et al. 2005; Schmitt et al. 2012), affecting the $\delta^{13} \mathrm{C}$ of ancient plant remains. However, since we do not intend to compare data from modern samples with data from the ancient plant remains in absolute terms, but just to identify the main factor in carbon isotope discrimination, variations due to the different $\delta^{13} \mathrm{C}$ of $\mathrm{CO}_{2}$ can be neglected. Thus, local environmental parameters appear to be the most important factors in determining $\delta^{13} \mathrm{C}_{\mathrm{plant}}$ variations. Among all the climatic parameters that might be involved in isotopic carbon discrimination, the most influential are those that are crucial to the growth and survival of plants (Ferrio et al. 2005).

In subarid regions, where water is scarce and its availability limited to certain periods of the year, $\delta^{13} \mathrm{C}$ in plants has been found to be dependent on local rainfall (Stewart et al. 1995; Weiguo et al. 2005; Guo and Xie 2006). Since it reflects changes in water availability, the $\delta^{13} \mathrm{C}$ of plants can indirectly help to assess climate shifts. Nonetheless, some specifications are required, especially concerning archaeological plant remains. The state of preservation of samples that are all charred remains could, in theory, affect the stable carbon isotope concentration. Tests on stable carbon isotope composition carried out on modern $\mathrm{C}_{3}$ and $\mathrm{C}_{4}$ plant material after different cooking procedures and laboratory simulations have shown contrasting results in terms of $\delta^{13} \mathrm{C}$ values depending on the processing methods used. Cereals are the least sensitive, since the $\delta^{13} \mathrm{C}$ before and after carbonization is substantially the same (Heaton et al. 2009; Fiorentino et al. 2012b). The biggest changes occur in charred wood (from $-0.5 \%$ to $-1.1 \%$ ) because the 2 major components of wood (cellulose and lignin) differ in their susceptibility to volatilization. Lignin contains less $\delta^{13} \mathrm{C}$ than cellulose (DeNiro and Hastorf 1985; McCarroll and Loader 2004) and is less volatile (Schleser et al. 1999). Consequently, charcoal generally includes a greater proportion of lignin-derived carbon, causing $\delta^{13} \mathrm{C}$ depletion. Nevertheless, because $\delta^{13} \mathrm{C}$ displays similar responses to climate in cellulose and lignin, this fractionation during charring does not override the climate signal of $\delta^{13} \mathrm{C}$ in charcoal (Hall et al. 2008).

The size of $\delta^{13} \mathrm{C}$ variations $(-0.5$ to $-1.1 \%$ ) in charred wood can be measured by AMS, but the selection of taxa should avoid resinous species such as Pinus sp., which are more sensitive to the effect of charring (Baldock and Smernik 2002). If applied in combination with archaeobotanical methods to pick out the right samples, carbon isotope analyses provide a simultaneous measure of $\delta^{13} \mathrm{C}$ and ${ }^{14} \mathrm{C}$ age, making it possible to study climate changes in an absolute chronological framework. 


\section{MATERIAL AND METHODS}

The archaeobotanical investigations led to the collection of several soil samples from the archaeological contexts being stratigraphically investigated. After being sieved, charcoal was separated from other remains (mainly microfauna and stones) and the anatomical features of charred wood tissue and seeds were analyzed by stereoscopic (Nikon SMZ 645) and metallographic (Nikon Eclipse ME600) microscopy.

Comparison with local plant reference material available at the Laboratory of Archaeobotany and Palaeoecology led to the taxonomic identification of 4962 charcoals and 3531 seed/fruits (Martinelli and Fiorentino 2008; Martinelli et al. 2010). Thirty-three samples were selected from among the archaeobotanical assemblage: 21 from Filo Braccio (Filucudi), 10 from Portella (Salina), and 2 from Punta Milazzese (Panarea).

Long-lived plants were avoided because their long lifespan could introduce uncertainty due to the old-wood effect. Moreover, the taxonomic identification of samples helped to select only plants with $\mathrm{a} \mathrm{C}_{3}$ photosynthetic pattern $\left(\delta^{13} \mathrm{C}\right.$ ranging from $-18 \%$ to $-32 \%$ ).

Cereals were preferred to wood in order to reduce the uncertainty of "charring effects" on the $\delta^{13} \mathrm{C}$. Where tree tissue was the only material available, non-resinous species were chosen. Annual edible fruits (1 specimen for sample), such as barley (Hordeum vulgare var. vulgare, H. vulgare var. distichum) and grape seeds (Vitis vinifera) were selected. When these remains were not available, small branches of trees and shrubs (diameter $\sim 1 \mathrm{~cm}$ ) were selected: olive (Olea europaea) and broom (Genista sp.) were the most frequent, followed by heather (Erica sp.), strawberry (Arbutus unedo), poplar/willow (Populus/Salix), plum trees (Prunus sp., Pomoidaeae), mastic (Pistacia lentiscus), and myrtle (Myrtus communis).

All the specimens were analyzed by AMS at the CEDAD laboratory, University of Salento, in accordance with standard procedures. Samples were mechanically cleaned under an optical microscope before undergoing a chemical cleaning procedure consisting of alternate treatment with acid $(10 \mathrm{~mL}$ of $1 \mathrm{M} \mathrm{HCl}$ for $10 \mathrm{hr}$ at room temperature), alkali $\left(10 \mathrm{~mL}\right.$ of $1 \mathrm{M} \mathrm{NaOH}$ at $\left.60{ }^{\circ} \mathrm{C}\right)$, and acid $(10 \mathrm{~mL}$ of $1 \mathrm{M} \mathrm{HCl}$ for $10 \mathrm{hr}$ at room temperature) (Quarta et al. 2005).

The purified sample material was then oven-dried and combusted to $\mathrm{CO}_{2}$ at $900{ }^{\circ} \mathrm{C}$ in sealed quartz tubes together with copper oxide and silver wool. The $\mathrm{CO}_{2}$ sample was then cryogenically purified and finally converted to graphite using hydrogen as a reducing medium and iron powder as catalyst (D'Elia et al. 2004). The graphite was pressed into the sample holders of the accelerator mass spectrometer for measurement of its isotopic composition (for further details see Calcagnile et al. 2005).

Conventional ${ }^{14} \mathrm{C}$ ages obtained at CEDAD (lab code LTL) were converted to calendar ages by using the IntCal09 calibration curve (Reimer et al. 2009) and OxCal v 4.1.6 (Bronk Ramsey 2009). In addition, 7 previous ${ }^{14} \mathrm{C}$ dates from the Portella site, performed at the Department of Earth Sciences-University of Rome I "La Sapienza" (lab code Rome) by liquid scintillation counting (LSC) (Calderoni and Martinelli 2005; Alberti 2011), were used to implement the ${ }^{14} \mathrm{C}$ database for the chronological pattern of human occupation in the Aeolian Archipelago during the Bronze Age (Figure 2). After all the ${ }^{14} \mathrm{C}$ dates were converted to calendar year, Calib-602 (http://calib.qub.ac.uk/ calib/) was used to sum calibrated probability distributions by year and normalized the area under the resulting distribution to 1 .

Summed probability distributions were used to identify periods in which the likelihood of human occupation was higher. The resulting curve ("multi-sample probability curve for archaeological 


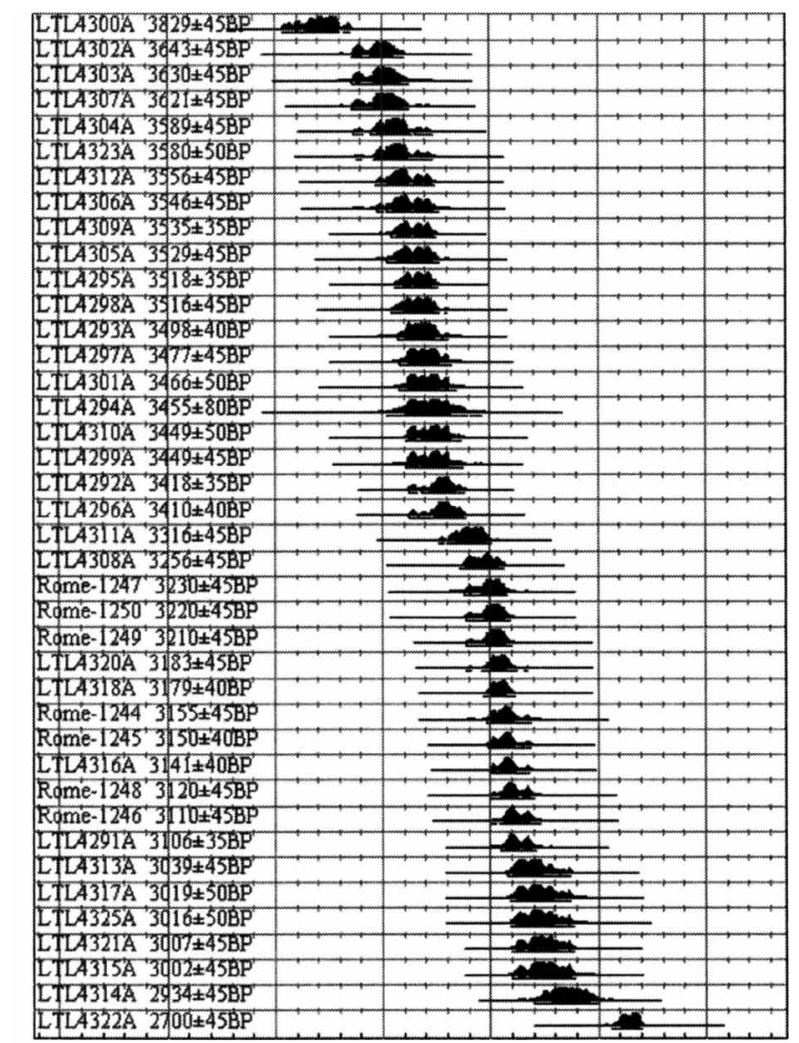

3500 CalBC 3000 CalBC 2500 CalBC 2000 CalBC 1500 CalBC 1000 CalBC 500 CalBC

Calibrated date

Figure 2 Probability distribution of the calibrated ages of the samples from Portella on Salina, Filo Braccio on Filicudi, and Punta del Milazzese on Panarea. The samples are ordered from oldest to youngest.

occupation") was compared with the number of sites for phase and the paleoclimate trend inferred from carbon isotope analyses to point out correlations between climate and site changes (Figure 3).

\section{RESULTS}

The AMS measurements performed on archaeobotanical samples at CEDAD are shown in Table 1. They indicate a time period roughly corresponding to the 2 nd millennium $\mathrm{BC}$, while the $\delta^{13} \mathrm{C}$ values range from $-30.1 \pm 0.5 \%$ (LTL4299A) to $-21.7 \pm 0.5 \%$ (LTL4313A), with an average value of $-25.8 \%$. The typical accuracy of the AMS ${ }^{14} \mathrm{C}$ measurements is $45 \mathrm{yr}$, and of the $\delta^{13} \mathrm{C}$ measurements $0.4 \%$, very close to the IRMS (isotope-ratio mass spectrometer) accuracy level (Table 1). The calibrated ${ }^{14} \mathrm{C}$ dates sheds light on the life cycle of each village, helping to refine the chronology of Aeolian settlement development (Martinelli 2010). The Filo Braccio chronology suggests that the site flourished between $\sim 2100$ and $1700 \mathrm{BC}(3650-3250 \mathrm{BP})$, a period corresponding to the Capo Graziano 1 cultural phase. Evidence of further occupation is visible in hut $G$ and area 1 (see LTL4296, 4311, 4308), although no direct sign of Capo Graziano 2 culture was found within these contexts (Martinelli et al. 2010). 


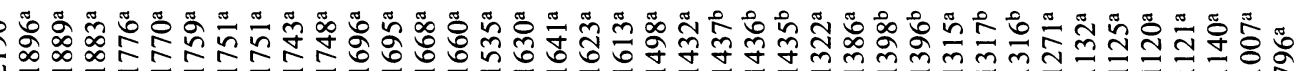

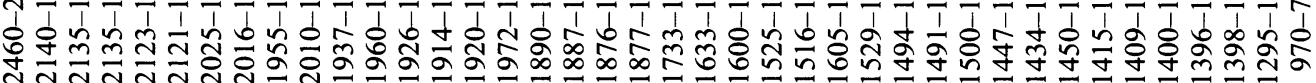

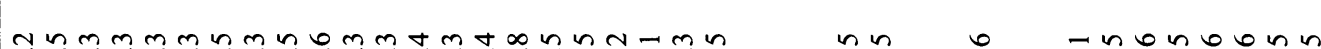
H H OH OH O O O O

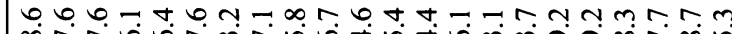

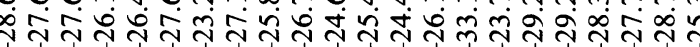

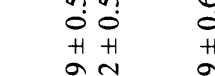

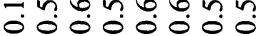
H H H H H H H H

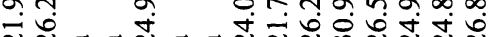

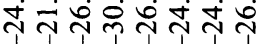

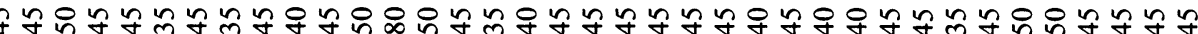

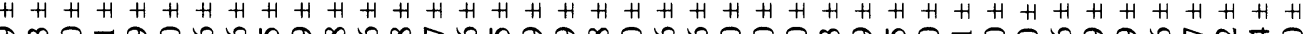
위ㅇㅠㅠ

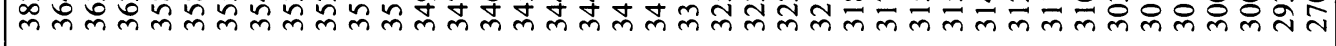

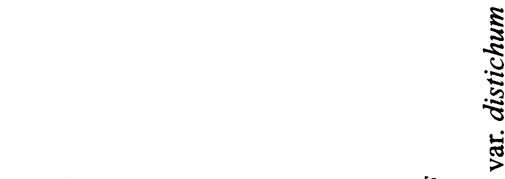<smiles>C[C@H]1C[C@H]1C[C@H]1C[C@@H]1C</smiles>

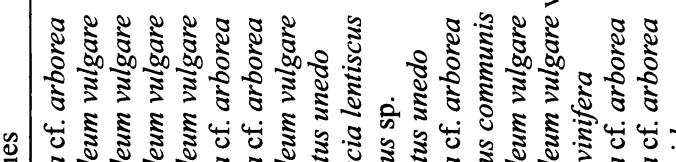

\&

$\vdots$

$2 \stackrel{8}{8}$

\& 8 \& 8

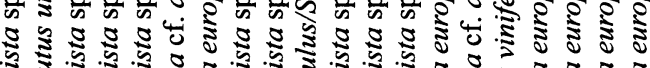
की

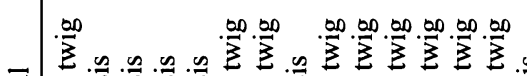

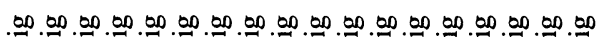

00.00 .000 .00000

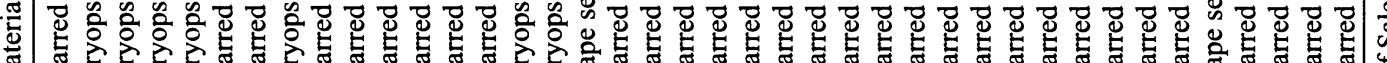
沉蛋

$\ddot{\circ}$

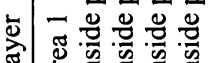

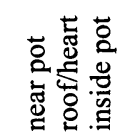

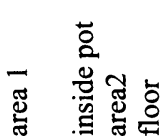

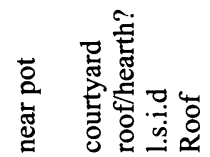

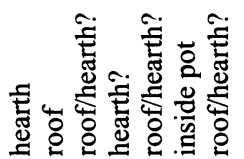

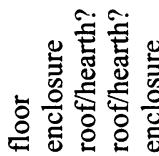

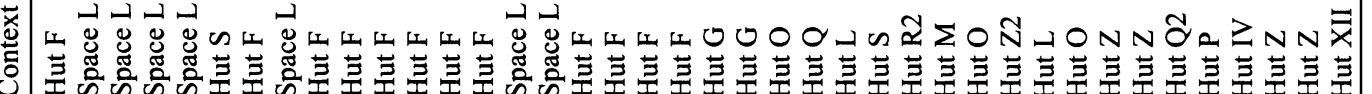

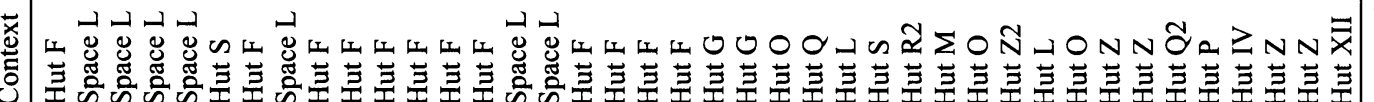

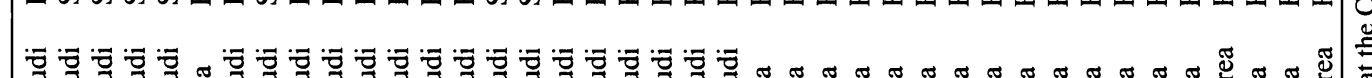

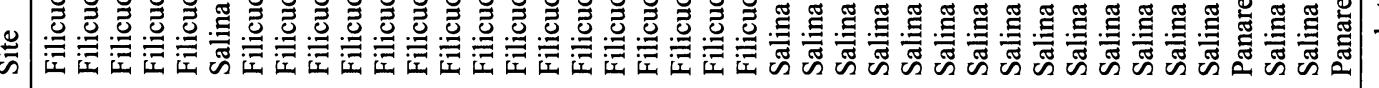




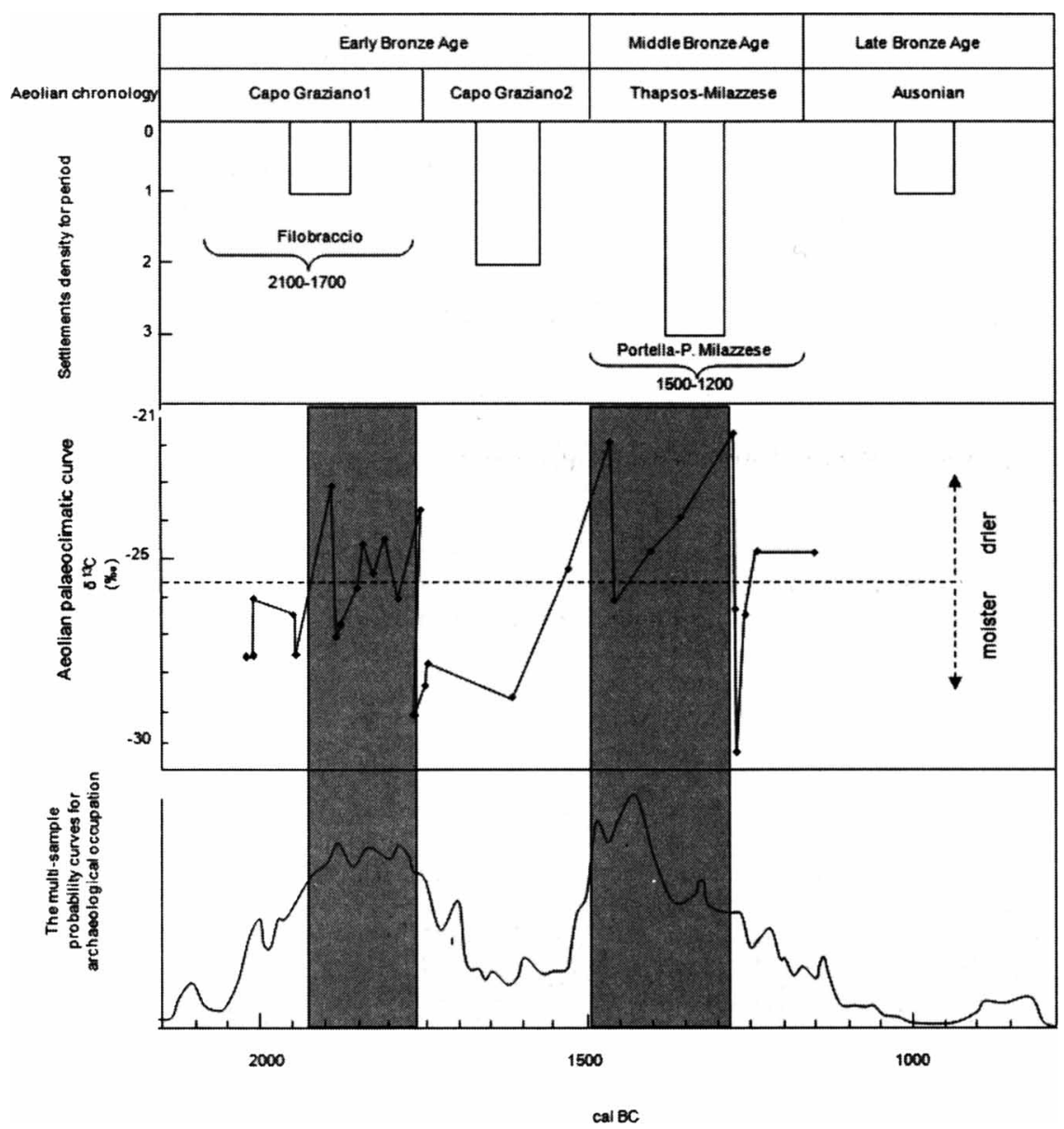

Figure 3 The sum of the probability of calibration curves of the $40{ }^{14} \mathrm{C}$ dates, the "multi-sample probability curve for archaeological occupation," is compared to the real number of settlements for phases and paleoclimate carbon isotope curve. Gray stripes indicate the periods of reduced rainfall that, despite all the forecasts, correspond to the phases with the highest probability of settlement spread.

The new ${ }^{14} \mathrm{C}$ measurements for Portella, performed by the CEDAD and Rome laboratories, restrict the timeframe of the settlement to 4 centuries between 1450 and 1100 BC (Martinelli 2005; Martinelli and Fiorentino 2008). Within this period, several occupation phases were identified on the basis of stratigraphical observations and spatial distribution of the huts. The ${ }^{14} \mathrm{C}$ chronology fits well with the traditional chronology, which dates the beginning of the Milazzese facies, i.e. the early MBA in the Aeolians, to the 15th century BC (Martinelli 2010). Of the 2 dates available for Punta Milazzese, one (LTL4321A) matches the last phase of Milazzese culture already identified at the Portella site, while the other (LTL4321A) belongs to the Ausonian horizon, although there are no archaeological traces of occupation datable to this facies.

The $\delta^{13} \mathrm{C}$ measurements enhance the value of the ${ }^{14} \mathrm{C}$ dating. Because of the simultaneous measurement of ${ }^{14} \mathrm{C}$ and stable carbon isotope ratios, changes in $\delta^{13} \mathrm{C}$ values can be interpreted in terms of well-dated paleoclimate signals. LTL4322A and LTL4300A were excluded because they do not fit with the chronological range, while LTL4301 shows an outlier $\delta^{13} \mathrm{C}$ value of $-33 \%$. At least 3 phases of reduced $\delta^{13} \mathrm{C}$ values (below $-25.8 \%$ ), interpretable as an index of moister conditions, can 
be distinguished: the first at 3650-3580 BP ( 2100-1950 BC); the second at 3450-3250 BP $(\sim 1700-1500 \mathrm{BC})$; and the last at 3050-2950 BP $(\sim 1250-1100 \mathrm{BC})$. Between these phases are periods of high $\delta^{13} \mathrm{C}$ values (more than $-25.8 \%$ ), corresponding to increased aridity: one at 3580-3450 BP ( 1950-1700 BC) and the other at 3250-3050 BP ( 1500-1250 BC). The drought periods, marked with gray stripes on Figure 3, are those that fit to the phases of higher human occupation (see peaks in the multi-sample probability curve). They, indeed, correspond to the end of Capo Graziano 1 and the beginning of Thapsos-Milazzese.

\section{DISCUSSION: PALEOCLIMATIC AND ARCHAEOLOGICAL IMPLICATIONS}

Our study of the Aeolian Islands provides an ideal opportunity to analyze the human-environment relationship, since there are less relevant variables and can therefore be easier understood than in continental contexts (Patton 1996). The identification of short-term climate changes provides a unique chance to study the way in which Aeolian communities have adapted to shortages of natural resources by changing food procurement strategies and/or developing contacts with external powers (Figure 3). Combining data on climate and human dynamics with the environmental changes recorded in the Gorgo Basso pollen sequence enables us to outline a complex system of correlations (Figure 4).

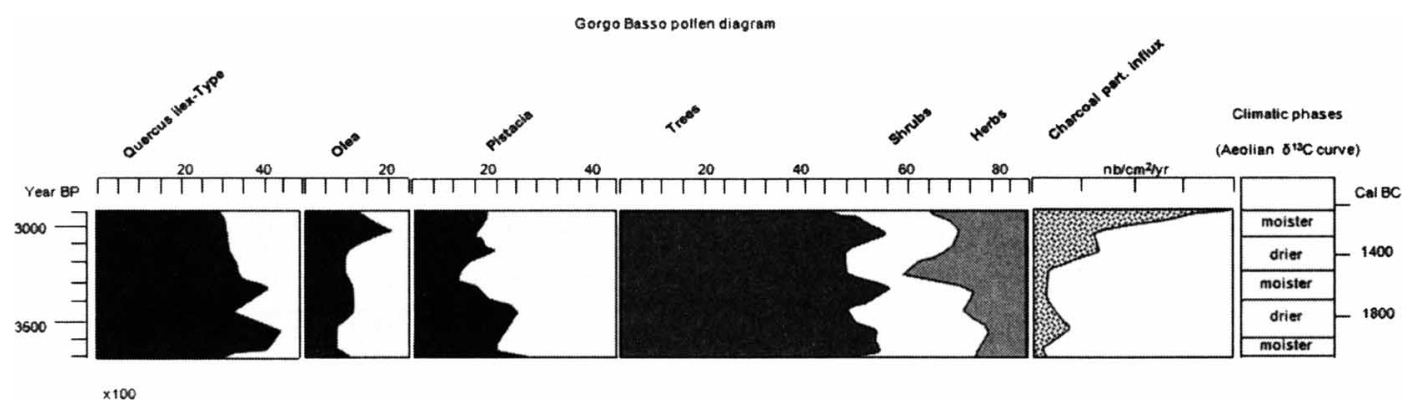

Figure 4 The Gorgo Basso pollen diagram (modified after Tinner et al. 2009) compared with the climate phases highlighted by the Aeolian curve.

The first Bronze Age occupation of the Aeolian Archipelago was characterized by settlements such as Filo Braccio (Filicudi) and Diana (Lipari), situated in lowland plains, where agriculture was practiced despite the limited availability of arable land. ${ }^{14} \mathrm{C}$ dating for this phase comes from material gathered in "Space L" in Filo Braccio, a courtyard devoted to cereal processing dated to 2100 $1950 \mathrm{BC}$. This period is characterized by low $\delta^{13} \mathrm{C}$ values, indicating moister conditions.

The Gorgo Basso pollen diagram (Figure 4) shows a general increase in trees during this phase, especially evergreen oak (Quercus ilex), and fewer shrubs (e.g. Pistacia lentiscus), which can be interpreted as a sign of moister conditions. The favorable environment apparently supported a farming economy that would have provided enough food to feed the local communities. Starting from the 20th century $\mathrm{BC}$, signs of disruption are evident in Capo Graziano 1 villages. ${ }^{14} \mathrm{C}$ dating, performed on material coming from fire layers in hut $\mathrm{F}$, reveals that the settlement was destroyed around $1700 \mathrm{BC}$. The centuries that preceded this episode are characterized by increased aridity, as suggested by the high $\delta^{13} \mathrm{C}$ values. At the same time, an open landscape developed in the surroundings of Gorgo Basso, where the arboreal coverage was limited and shrubs and herbs prevailed. The reduced number of microcharcoal within the pollen sequence, above all in the last part of the phase, suggests that the decrease in trees was not due to human activity but was more likely the response of natural plant cover to drought conditions. 
The effects of climate on local natural resources could have undermined the basis of subsistence for the Aeolian agricultural communities and weakened the settlers against their enemies. The Capo Graziano 2 phase saw the introduction of new elements, especially the development of contacts with Mycenaean traders who crossed the western Mediterranean in search of minerals. The role of Aeolians in the trade system also influenced settlement patterns. Lowland sites were abandoned and people moved to the hilltops where they founded villages in favorable positions in order to control the marine routes. Lipari and Filicudi were still the only inhabited islands, but in both cases people relocated to sites in prominent positions. The Lipari Acropolis was settled for the first time, while on Filicudi Island, settlers relocated to La Montagnola, a new site on the higher promontory. ${ }^{14} \mathrm{C}$ dating performed on Filo Braccio samples suggests that scattered occupation occurred in huts $\mathrm{F}$ and $\mathrm{G}$ and Area 1, although there is no archaeological evidence of Capo Graziano 2.

Despite the favorable conditions that characterize the period, as suggested by the low $\delta^{13} \mathrm{C}$ values of samples and the increased arboreal pollen in the Gorgo Basso diagram, the Aeolians did not practice farming. It is likely that trade supplied food and other goods. The importance of trade increased during the Milazzese phase ( 1500-1300 BC), when the "Mycenaeanized" Aeolian communities struggled against their neighbors for control of maritime trade and pillaged the coastal peninsular settlements.

The struggle between the Aeolians and the Tyrrhenian population took place during a period of reduced rainfall, characterized by high $\delta^{13} \mathrm{C}$ values, during which the Mediterranean arboreal vegetation suffered from the combined effect of drought and human activity. The reduction of tree cover in the Gorgo Basso sequence coincides with an increase in microcharcoal concentration. This increase was too large and too rapid to be attributed to natural factors alone, and must therefore have been at least partly the result of human action. The decrease in the $\delta^{13} \mathrm{C}$ of AMS-dated plants after $\sim 1300 \mathrm{BC}$ indicates moister conditions, which may also have favored the spread of olive trees in the Gorgo Basso area.

Despite the favorable environment, the Aeolian system collapsed during the Late Bronze Age. Traces of disruption are evident in all the settlements occupied during the Middle Bronze Age, most of which were abandoned and never repopulated. Scholars attribute this development to the invasion of the "Ausonians," a group of invaders from the Italian mainland who destroyed all the settlements except the Lipari Acropolis, which was used as a center of control. The conflict may have had many causes, including the pressure exercised by the "Mycenaeanized" Aeolians during the Milazzese phase on their mainland neighbors, as well the inability of the islands to control maritime routes after the rise of the Phoenicians.

\section{CONCLUSION}

Rethinking the role of botanical remains can expand the potential of AMS. If selected in an appropriate manner, plants from archaeological contexts can provide not only a reliable chronological framework, but data with which patterns of short-term paleoclimate changes can be established. New measurements of ${ }^{14} \mathrm{C}$ and $\delta^{13} \mathrm{C}$ on 33 samples collected in 3 sites in the Aeolian Archipelago provide a robust chronology of settlement dynamics during the Bronze Age. The opportunity to integrate human history with environmental developments during the Bronze Age prompted our adoption of a combined approach using carbon isotope analyses to identify trends in rainfall variation during the 2 nd millennium BC. The reliability of this method was tested, and climate signals were found to be consistent with changes in the vegetal cover recorded in the Gorgo Basso pollen sequence. Thanks to the high chronological resolution ensured by the use of AMS techniques, climate signals could be integrated with the history of Aeolian communities and the resilience of settlers to the harsh environment was evaluated. 


\section{REFERENCES}

Alberti G. 2011. Radiocarbon evidence from the Middle Bronze Age settlement at Portella (Aeolian Islands, Italy): chronological and archaeological implications. Radiocarbon 53(1):1-12.

Baldock JA, Smernik RJ. 2002. Chemical composition and bioavailability of thermally altered Pinus resinosa (Red pine) wood. Organic Geochemistry 33(9):1093109.

Bernabò Brea L, Cavalier M. 1968. Stazioni preistoriche delle isole Panarea, Salina e Stromboli. Meligunis Lipara. Volume III. Palermo: Flaccovio.

Bernabò Brea L, Cavalier M. 1991. Filicudi insediamenti dell'età del Bronzo. Meligunis Lipara. Volume VI. Palermo: Accademia di Scienze, Lettere e Arti.

Bietti Sestieri AM. 2010. L'Italia nell'età del Bronzo e del Ferro. Roma: Carrocci editore.

Bronk Ramsey C. 2009. Bayesian analysis of radiocarbon dates. Radiocarbon 51(1):337-60.

Calcagnile L, Quarta G, D'Elia M. 2005. High resolution accelerator-based mass spectrometry: precision, accuracy and background. Applied Radiation and Isotopes 62(4):623-9.

Calderoni G, Martinelli MC. 2005. Cronologia radiocarbonio. In: Martinelli MC. Il villaggio dell'età del Bronzo medio di Portella a Salina nelle Isole Eolie. Florence: Istituto Italiano di Preistoria e Protostoria. p 287-98.

DeNiro MJ, Hastorf CA. 1985. Alteration of ${ }^{15} \mathrm{~N} /{ }^{14} \mathrm{~N}$ and ${ }^{13} \mathrm{C} /{ }^{12} \mathrm{C}$ ratios of plant matter during the initial stages of diagenesis: studies utilizing archaeological specimens from Perù. Geochimica Cosmochimica Acta 49(1):97-115.

D’Elia M, Calcagnile L, Quarta G, Rizzo A, Sanapo C, Laudisa M, Toma U, Rizzo A. 2004. Sample preparation and blank values at the AMS radiocarbon facility of the University of Lecce. Nuclear Instruments and Methods in Physics Research B 223-224:27883.

Ehleringer JR, Hall A, Farquar GD. 1993. Stable Isotopes and Plant Carbon-Water Relations. San Diego: Academic Press.

Farquar GD, Ehleringer JR, Hubick KT. 1989. Carbon isotope discrimination and photosynthesis. Annual Review of Plant Physiology and Plant Molecular Biology 40:530-7.

Farquhar GD, O'Leary MH, Berry JA. 1982. On the relationship between carbon isotope discrimination and the intercellular carbon dioxide concentration in leaves. Australian Journal of Plant Physiology 9:12137.

Ferrio JP, Araus JL, Buxó R, Voltas J, Bort J. 2005. Water management practices and climate in ancient agriculture: inference from the stable isotope composition of Archaeobotanical remains. Vegetation, History and Archaeobotany 14:510-7. [Data available at http:// web.udl.es/usuaris/x3845331/AIRCO2_LOESS.xls].
Fiorentino G, Caracuta V, Calcagnile L, D'Elia M, Matthiae P, Mavelli F, Quarta G. 2008. Third millennium B.C. climate change in Syria highlighted by carbon stable isotope analysis of ${ }^{14} \mathrm{C}$-AMS dated plant remains from Ebla. Palaeogeography, Palaeoclimatology, Palaeoecology 266(1-2):51-8.

Fiorentino G, Caracuta V, Volpe G, Turchiano M, Quarta G, D'Elia M, Calcagnile L. 2009. The first millennium $\mathrm{AD}$ climate fluctuations in the Tavoliere Plain (Apulia, Italy): new data from the ${ }^{14} \mathrm{C}$ AMS-dated plant remains from the archaeological site of Faragola. Nuclear Instruments and Methods in Physics Research B 268(7-8):1084-7.

Fiorentino G, Caracuta V, Quarta G, Calcagnile L, Morandi-Bonaccossi D. 2012a. Palaeoprecipitation trends and cultural changes in Syrian proto-historic communities: the contribution of $\delta^{13} \mathrm{C}$. In: Kneisel J, Kirleis W, Dal Corso M, Taylor N, Tiedtke V, editors. Collapse or Continuity? Environment and Development of Bronze Age Human Landscapes. Bonn: Verlag Dr Rudolph Habelt GmbH. p 17-34.

Fiorentino G, Caracuta G, Casiello G, Longobardi F, Sacco A. 2012b. Studying ancient crop provenance: implication from $\delta^{13} \mathrm{C}$ and $\delta^{15} \mathrm{~N}$ of charred barley in a Middle Bronze Age silo at Ebla (NW Syria). Rapid Communications in Mass Spectrometry 26(3):327-35.

Guo G, Xie G. 2006. The relationship between plant stable carbon isotope composition, precipitation and satellite data, Tibet Plateau, China. Quaternary International 144(1):68-71.

Hall G, Woodborne S, Scholes M. 2008. Stable carbon isotope ratios from archaeological charcoal as palaeoenvironmental indicators. Chemical Geology 247(3): 384-400.

Heaton THE. 1999. Spatial, species, and temporal variations in the ${ }^{13} \mathrm{C} /{ }^{12} \mathrm{C}$ ratios of $\mathrm{C}_{3}$ plants: implications for palaeodiet studies. Journal of Archaeological Science 26(6):637-49.

Heaton THE, Jones G, Halstead P, Tsipropoulos T. 2009. Variations in the ${ }^{13} \mathrm{C} /{ }^{12} \mathrm{C}$ ratios of modern wheat grain, and implications for interpreting data from Bronze Age Assiros Toumba, Greece. Journal of Archaeological Science 36(10):2224-33.

Maramai A, Graziani L, Tinti S. 2005. Tsunamis in the Aeolian Islands (southern Italy): a review. Marine Geology 215(1-2):11-21.

Martinelli MC. 2005. Il Villaggio dell'età del Bronzo medio di Portella a Salina nelle Isole Eolie. Florence: Istituto Italiano di Preistoria e Protostoria.

Martinelli MC. 2010. Archeologia delle Isole Eolie. Il Villaggio dell'età del Bronzo medio di Portella a Salina. Ricerche 2006 e 2008. Muggiò (Mi): Rebus editore.

Martinelli MC, Fiorentino G. 2008. The "fires" of Aeolian villages at the end of Middle Bronze Age: the case of Portella site in the Salina island. In: Fiorentino G, 
Magri D. Charcoal from the Past. Proceedings of the 3rd IMA. British Archaeological Reports 1807. Oxford: Archaeopress. p 177-90.

Martinelli MC, Fiorentino G Prosdocimi B, D’Oronzo C, Levi ST, Mangano G, Stellati A, Wolff N. 2010. Nuove ricerche nell'insediamento sull'istmo di Filo Braccio a Filicudi. Nota preliminare sugli scavi 2009. Origini 32:285-314.

Mayewski PA, Rohling, EE, Stager JC, Karlén W, Maasch KA, Meeker LD, Meyerson EA, Gasse F, van Kreveld S, Holmgren K, Lee-Thorp J, Rosqvist G, Rack F, Staubwasser M, Schneider R, Steig EJ. 2004. Holocene climate variability. Quaternary Research 62(3):243-55.

McCarroll D, Loader NJ. 2004. Stable isotopes in tree rings. Quaternary Science Reviews 23:771-801.

Morelli C, Giese P, Cassinis R, Colombi B, Guerra I, Luongo G, Scarascia S, Schutte KG. 1975. Crustal structure of southern Italy. A seismic refraction profile between Puglia-Calabria-Sicily. Bollettino Geofisico Teorico Applicato 12:275-309.

O'Leary MH. 1995. Environmental effects on carbon fractionation in terrestrial plants. In: Wada E, Yoneyama T, Minagawa M, Ando T, Fry BD, editors. Stable Isotopes in the Biosphere. Kyoto: Kyoto University Press. p 78-91.

Patton M. 1996. Islands in Time. Island Sociogeography and Mediterranean Prehistory. New York: Routledge.

Quarta G, D'Elia M, Valzano D, Calcagnile L. 2005. New bomb pulse radiocarbon records from annual tree rings in the Northern Hemisphere temperate region. Radiocarbon 47(1):27-30.

Reimer PJ, Baillie MGL, Bard E, Bayliss A, Beck JW, Blackwell PG, Bronk Ramsey C, Buck CE, Burr GS, Edwards RL, Friedrich M, Grootes PM, Guilderson TP, Hajdas I, Heaton TJ, Hogg AG, Hughen KA, Kaiser KF, Kromer B, McCormac FG, Manning SW, Reimer RW, Richards DA, Southon JR, Talamo S, Turney CSM, van der Plicht J, Weyhenmeyer CE. 2009. IntCal09 and Marine09 radiocarbon age calibration curves, 0-50,000 years cal BP. Radiocarbon 51(4): 1111-50.

Riehl S, Bryson RA and Pustovoytov KE. 2008. Changing growing conditions for crops during the Near Eastern Bronze Age (3000-1200 BC): the stable carbon isotope evidence. Journal of Archaeological Science 35(4):1011-2.

Roberts CN, Eastwood W, Kuzucuolu C, Fiorentino G, Caracuta V. 2011. Climatic, vegetation and cultural change in the eastern Mediterranean during the midHolocene environmental transition. The Holocene 21(1):147-62.

Sadori L, Zanchetta G, Giardini M. 2008. Last Glacial to
Holocene palaeoenvironmental evolution at Lago di Pergusa (Sicily, southern Italy) as inferred by pollen, microcharcoal, and stable isotopes. Quaternary International 181(1):4-14.

Schleser GH, Helle G, Lücke A, Vos H. 1999. Isotope signals as climate proxies: the role of transfer functions in the study of terrestrial archives. Quaternary Science Reviews 18:927-43.

Schmitt J, Schneider R, Elsig J, Leuenberger D, Lourantou A, Chappellaz J, Köhler P, Joos F, Stocker TF, Leuenberger M, Fischer H. 2012. Carbon isotope constraints on the deglacial $\mathrm{CO}_{2}$ rise from ice cores. Science 336(608):711-4.

Stewart GR, Turnbull MH, Schmidt S, Erskine PD. 1995. ${ }^{13} \mathrm{C}$ natural abundance in plant communities along a rainfall gradient: a biological integrator of water availability. Australian Journal of Plant Physiology 22(1): 51-5.

Taylor JA, Orr JC. 2000. The natural latitudinal distribution of atmospheric $\mathrm{CO}_{2}$. Global and Planetary Change 26(4):375-86.

Théry-Parisot I, Chabal L, Chrzavzez J. 2010. Anthracology and taphonomy, from wood gathering to charcoal analysis. A review of the taphonomic processes modifying charcoal assemblages, in archaeological contexts. Palaeogeography, Palaeoclimatology, Palaeoecology 291(1-2):142-53.

Tinner W, van Leeuwen JFN, Colombaroli D, Vescovi E, van der Knaap WO, Henne PD, Pasta S, D'Angelo S, La Mantia T. 2009. Holocene environmental changes at Gorgo Basso, a Mediterranean coastal lake in southern Sicily, Italy. Quaternary Science Reviews 28: 1498-510.

Troia A. 1998. Contributo alla conoscenza delle Isole Eolie (Sicilia). Informatore Botanico Italiano 29(2-3): 262-6.

Vernet JL, Pachiaudi C, Bazile, F, Durand A, Fabre L, Heinz C, Solari ME, Thiebault S. 1996. Le $\delta^{13} \mathrm{C}$ de charbons de bois préhistoriques et historiques méditerranées, de 35000 BP a l'actuel. Premiers résultats. Comptes Rendus de l'Académie des Sciences Paris 323(2a):319-24.

Weiguo L, Xiahong F, Youfeng N, Qingle Z, Yunning C. 2005. $\delta^{13} \mathrm{C}$ variation of $C_{3}$ and $C_{4}$ plants across an Asian monsoon rainfall gradient in arid northwestern China. Global Change Biology 11(7):1094-100.

Williamson I, Sabath MD. 1984. Small population instability and Island settlement patterns. Human Ecology 12(1):21-33.

Zohary D, Hopf M. 2000. Domestication of Plants in the Old World. 3rd edition. New York: Oxford University Press. 